\title{
Pengukuran dan Analisa Data Radiasi Matahari di Stasiun Klimatologi Muaro Jambi
}

\section{The Measurement and Analysis of Solar Radiation Data at the Muaro Jambi Climatology Station}

\author{
Yesi Sianturi ${ }^{1 *}$, Chinthya M Simbolon ${ }^{2}$ \\ ${ }^{1}$ Pusat Layanan Informasi Iklim Terapan, Badan Meteorologi Klimatologi dan Geofisika Jakarta \\ 2 Stasiun Klimatologi Muaro Jambi, Jl. Tembesi-Jambi, Kota Jambi \\ *E-mail: yculina@gmail.com
}

Naskah masuk: 08 November $2020 \quad$ Naskah diperbaiki: 15 Maret $2021 \quad$ Naskah diterima: 31 Maret 2021

\begin{abstract}
ABSTRAK
Radiasi matahari merupakan salah satu besaran paling penting dalam penelitian di bidang klimatologi, karena berperan sebagai penggerak dalam sebagian besar proses dinamis di atmosfer. Pengukuran beberapa parameter radiasi matahari di Stasiun Klimatologi Muaro Jambi dilakukan menggunakan satu set instrumen automatic solar radiation station (ASRS) sejak tahun 2017. Dalam tulisan ini, metode pengukuran, kontrol kualitas data, dan hasil analisa variabilitas dari tiga jenis radiasi matahari radiasi langsung, radiasi baur, dan radiasi global - dalam periode 2018 - 2019, telah dijabarkan. Hasil kontrol kualitas data menunjukkan bahwa secara umum ketiga parameter radiasi tersebut memiliki rentang nilai yang baik. Selama tahun 2018 - 2019, ketiga parameter radiasi tersebut mencapai puncak pada pukul 13.00 LT dan nilai rata rata akumulasi radiasi global dalam sehari mencapai $4.4 \pm 1.0 \mathrm{kWh} / \mathrm{m}^{2}$ day $^{-1}$. Puncak insolasi di Stasiun Klimatologi Muaro Jambi terjadi pada bulan Maret dan September, yang bertepatan dengan waktu terjadinya equinox. Kuatnya pertumbuhan awan di wilayah Jambi turut mempengaruhi pola radiasi yang mencapai permukaan bumi.
\end{abstract}

Kata kunci: radiasi matahari, automatic solar radiation station, energi surya

\begin{abstract}
Solar radiation is one of the most important quantities in research in the field of climatology, as it acts as a driving force in most of the dynamic processes in the atmosphere. Measurement of several solar radiation parameters at the Jambi Climatology Station has been carried out using a set of instruments called the automatic solar radiation station (ASRS) since 2017. In this paper, the measurement method, data quality control, and analysis of variability of the three types of solar radiation - direct radiation, diffuse radiation, and global radiation - in the period of 2018 - 2019, have been described. The results of data quality control indicate that in general, the three radiation parameters have good spread of values. In the 2018 - 2019 period, the three parameters reached their peak at 13.00 LT and the daily average global radiation reached $4.4 \pm 1.0 \mathrm{kWh} / \mathrm{m}^{2}$ day $^{-1}$. The peak of insolation at the Jambi Climatology Station occurred in March and September, which coincided with the equinox events. The significant cloud growth in the Jambi region affects the radiation pattern that reaches the earth surface.
\end{abstract}

Keywords: solar radiation, automatic solar radiation station, solar energy 


\section{Pendahuluan}

Radiasi matahari merupakan salah satu parameter cuaca yang paling berpengaruh dalam sistem iklim, dimana seluruh fenomena cuaca dan iklim pada mulanya disebabkan oleh variasi distribusi penerimaan radiasi matahari. Fluktuasi intensitas radiasi matahari yang diterima di permukaan bumi membentuk pola iklim dalam berbagai skala waktu [1]. Tidak hanya mempengaruhi sistem cuaca dan iklim, pola radiasi matahari juga memberikan informasi penting dalam berbagai sektor, seperti pertanian, sumber daya air, dan energi. Meskipun demikian, radiasi matahari merupakan salah satu parameter cuaca yang belum banyak ditinjau dalam kajian iklim di Indonesia, mengingat sedikitnya jaringan pengamatan radiasi matahari di wilayah Indonesia.

Radiasi matahari merupakan gelombang elektromagnetik yang dibangkitkan dari proses fusi nuklir di inti matahari. Pada kondisi cuaca cerah, energi yang sampai ke permukaan terluar atmosfer bumi rata-rata sebesar 1367 $\mathrm{W} / \mathrm{m}^{2}$, dalam bentuk gelombang pendek $( \pm 4,0$ $\mu \mathrm{m})$, meskipun yang sampai ke permukaan daratan dan lautan hanya sebagian dari nilai tersebut. Radiasi yang memasuki atmosfer bumi mengalami beberapa jenis proses sebagian dari radiasi tersebut dibaurkan oleh partikel partikel yang ada di atmosfer, sebagian diserap oleh partikel partikel tersebut, sebagian diserap oleh permukaan bumi [2]. Total dari radiasi gelombang pendek yang mencapai permukaan bumi (horizontal) biasa disebut sebagai radiasi global atau global horizontal radiation. Radiasi global ini terdiri dari dua jenis komponen, yakni komponen radiasi langsung (direct radiation) dan komponen radiasi baur (diffuse radiation).

Studi terkait profil radiasi matahari di wilayah Indonesia telah dilakukan dalam beberapa kesempatan, terutama untuk mendukung analisa potensi energi surya di Indonesia. Potensi energi matahari biasanya dihitung menggunakan persamaan empiris dengan masukan parameter meteorologi lain, dimana parameter yang paling umum digunakan adalah lama penyinaran matahari [3 - 4]. Rumbayan [5] menggunakan metode jaringan syaraf tiruan dengan menggunakan masukan beberapa parameter meteorologi untuk memetakan potensi energi matahari untuk seluruh wilayah Indonesia. Dalam beberapa studi tersebut, ditemukan bahwa radiasi matahari di wilayah Indonesia bagian timur cenderung memiliki nilai yang lebih tinggi dan pola seasonal yang lebih jelas dibandingkan wilayah barat Indonesia [56]. Radiasi di beberapa wilayah di Indonesia juga terlihat dipengaruhi oleh gerak semi tahunan dan kondisi kejernihan atmosfer [3-4].

Pengamatan radiasi matahari di wilayah Indonesia terdiri dari pengamatan lama penyinaran matahari dan pengamatan intensitas radiasi matahari. Salah satu instrumen pengamatan radiasi matahari yang mengukur kedua kuantitas tersebut adalah automatic solar radiation station (ASRS). Setiap unit ASRS terdiri dari 3 pyranometer dan 1 pyrheliometer, dimana ketiga pyranometer tersebut dipasang secara terpisah untuk mengukur komponen radiasi matahari yang berbeda. Data radiasi dari beberapa instrumen ASRS juga telah digunakan dalam studi validasi data reanalisis [7]. Di Stasiun Klimatologi Muaro Jambi, satu unit ASRS dipasang pada tahun 2017 dan menyediakan data radiasi matahari dengan resolusi temporal yang tinggi (10 menit). Analisa dari data radiasi matahari ini dapat memberikan informasi awal mengenai pola radiasi matahari yang dibutuhkan dalam berbagai sektor terapan.

\section{Metode Penelitian}

Instrumen pengukuran. Pengukuran radiasi matahari di Stasiun Klimatologi Muaro Jambi dilakukan dengan menggunakan dua jenis sensor, yakni pyranometer dan pyrheliometer, yang dilengkapi dengan photo-sensitive material atau termokopel untuk menangkap radiasi matahari. Pengukuran radiasi matahari diklasifikasikan sesuai dengan jenis radiasi yang diukur, respon spektral, serta kegunaannya. Pyranometer yang terdapat di Stasiun Klimatologi Muaro Jambi digunakan untuk mengukur radiasi global (global horizontal irradiance/ GHI), radiasi baur (diffuse horizontal irradiance/ $\mathrm{DHI}$, dan radiasi matahari reflektif/pantulan (reflective irradiance), dimana ketiga instrumen tersebut ditempatkan secara horizontal. Di sisi lain, pyrheliometer digunakan untuk mengukur besaran radiasi matahari langsung (direct normal irradiance/ DNI).

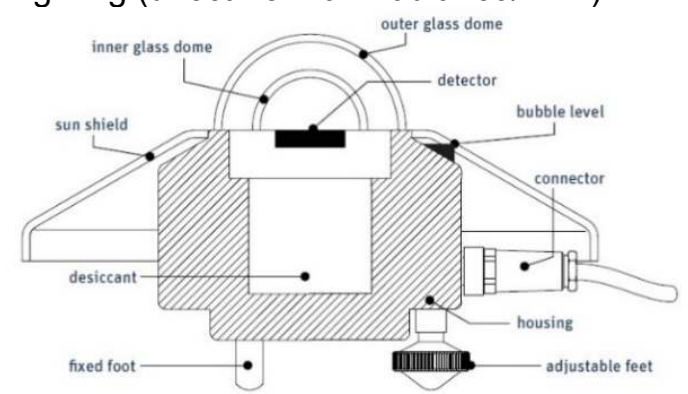

Gambar 1. Struktur pyranometer. (Sumber: manual handbook ASRS [8]) 


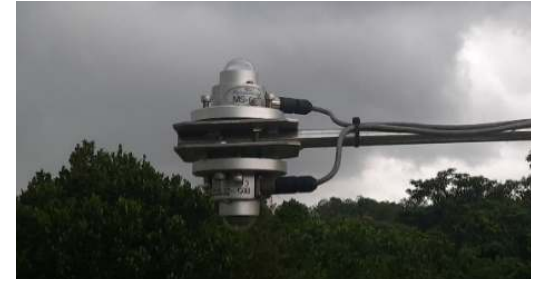

(a)

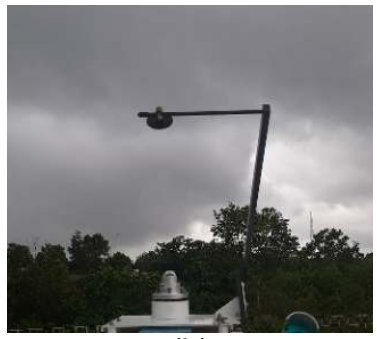

(b)

Gambar 2. Pyranometer yang mengukur (a) radiasi global dan radiasi pantul, serta b) radiasi baur. (Sumber: dokumentasi penulis)

Pyranometer yang dipasang secara horizontal dan seutuhnya menghadap langit tanpa penghalang digunakan untuk mengukur radiasi global matahari (GHI). Untuk mendapatkan nilai radiasi baur, salah satu pyranometer dilengkapi oleh komponen berbentuk 'lengan' (sun tracker) yang secara konstan menutupi lensa pyranometer dari cahaya matahari langsung. Radiasi pantulan diukur menggunakan pyranometer yang ditempatkan secara berlawanan arah $\left(180^{\circ}\right)$ dengan pyranometer global (menghadap permukaan bumi), dimana radiasi yang diukur merupakan radiasi yang dipantulkan dari permukaan tanah.

Pyrheliometer digunakan untuk mengukur berkas sinar matahari langsung yang dipasang beriringan dengan sun tracker untuk mengarahkan sensor ke arah sudut datang matahari (rasio aspek tabung $\pm 5^{\circ}$ ). Pyrheliometer didesain untuk mengikuti sudut normal matahari, berbeda dengan pyranometer yang dipasang secara horizontal. Perangkat pendukung sun tracker yang dipasang untuk membantu kerja dari pyrheliometer antara lain adalah kaki sun tracker, Global Position System (GPS), sun sensor, dan microcomputer. Kaki dari sun tracker berfungsi sebagai penopang untuk memastikan sun tracker pada posisi lurus; GPS dipasang untuk memperhitungkan koordinat dan waktu pengamatan, dimana perhitungan tersebut didasarkan pada lokasi penempatan sensor dan posisi relatif matahari. Sun sensor digunakan untuk mengarahkan lengan ke posisi matahari secara tepat dan microcomputer digunakan untuk menghitung posisi matahari dan memberi komando arah pada sun tracker.

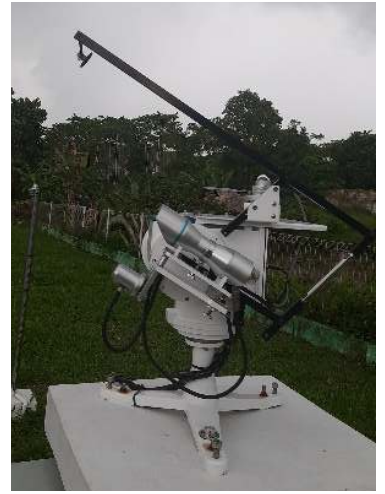

(a)
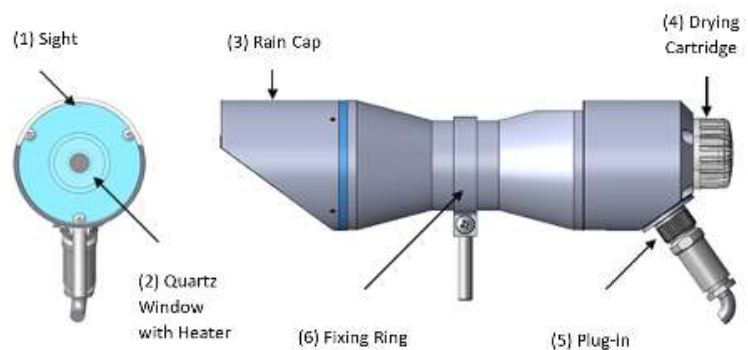

(b)

Gambar 3. Pyrheliometer: a) Bentuk fisik b) Struktur alat. (Sumber: dokumentasi penulis dan manual handbook ASRS [9])

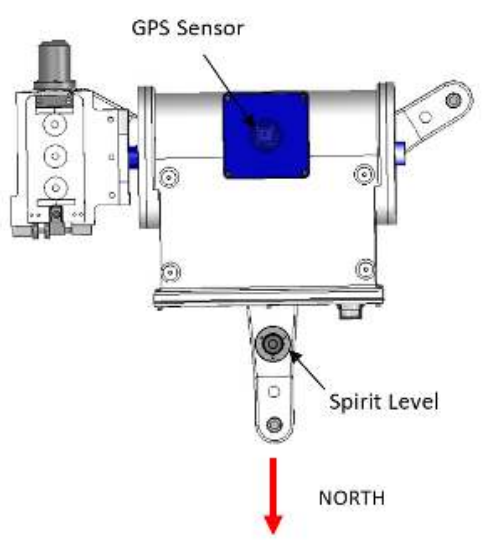

(a)

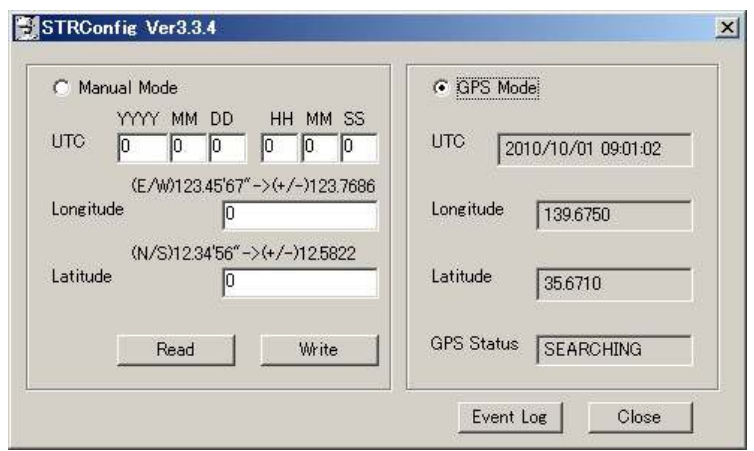

(b)

Gambar 4. Bagian pendukung pyrheliometer, (a) hardware dan (b) software. (Sumber: Manual handbook ASRS [8] dan dokumentasi penulis) 
Semua besaran radiasi matahari tersebut diukur dalam interval waktu 10 menit, dimana nilai yang tercatat merupakan nilai sesaat (instantaneous value), atau disebut sebagai solar irradiance dan memiliki satuan $W / \mathrm{m}^{2}$. Dalam beberapa konteks, radiasi matahari juga biasa dinyatakan sebagai nilai akumulasi dalam jangka waktu tertentu dan memiliki satuan $/ / m^{2}\left(W s / m^{2}\right)$ atau dalam keperluan perhitungan potensi energi surya, sering dituliskan dalam $W h / m^{2}$ dan disebut sebagai solar radiation [10]. Dalam tulisan ini, data Januari 2018 hingga Desember 2019 digunakan dalam analisa dari tiga jenis parameter radiasi, yakni radiasi global, radiasi baur, dan radiasi langsung, untuk melihat variabilitas harian dan bulanan dari ketiga parameter tersebut.

Kontrol Kualitas Data Radiasi Matahari. Sebelum melakukan analisis terhadap data radiasi matahari di Stasiun Klimatologi Muaro Jambi, proses kontrol kualitas data dilakukan terhadap hasil pengukuran. Metode kontrol kualitas data yang dilakukan adalah eliminasi nilai yang melewati batas yang memungkinkan secara fisis (physically possible limit) dan batas nilai ekstrim (extremely rare limits) untuk menghilangkan data yang disebabkan oleh kesalahan pengukuran dan outlier. Kontrol kualitas data dilakukan pada ketiga jenis radiasi yang diukur di Stasiun Klimatologi Muaro Jambi, yakni radiasi global (GHI), radiasi baur $(\mathrm{DHI})$, dan radiasi langsung (DNI). Batas nilai yang memungkinkan secara fisis dan batas nilai ekstrim dapat dituliskan sebagai berikut [11]:

Tabel 1. Batas nilai yang memungkinkan secara fisis.

\begin{tabular}{ccc}
\hline Parameter & $\begin{array}{c}\text { Batas } \\
\text { bawah }\end{array}$ & Batas atas \\
\hline $\mathrm{GHI}$ & $-4 \mathrm{~W} / \mathrm{m}^{2}$ & $1.5 S_{a}\left(\mu_{0}\right)^{12}+100 \mathrm{~W} / \mathrm{m}^{2}$ \\
$\mathrm{DHI}$ & $-4 \mathrm{~W} / \mathrm{m}^{2}$ & $0.95 S_{a}\left(\mu_{a}\right)^{12}+100 \mathrm{~W} / \mathrm{m}^{2}$ \\
$\mathrm{DNI}$ & $-4 \mathrm{~W} / \mathrm{m}^{2}$ & $s_{a}$ \\
\hline
\end{tabular}

Tabel 2. Batas nilai ekstrim.

\begin{tabular}{ccc}
\hline Parameter & $\begin{array}{c}\text { Batas } \\
\text { bawah }\end{array}$ & Batas atas \\
\hline $\mathrm{GHI}$ & $-2 \mathrm{~W} / \mathrm{m}^{2}$ & $1.2 S_{a}\left(\mu_{0}\right)^{12}+50 \mathrm{~W} / \mathrm{m}^{2}$ \\
$\mathrm{DHI}$ & $-2 \mathrm{~W} / \mathrm{m}^{2}$ & $0.75 S_{0}\left(\mu_{0}\right)^{12}+30 \mathrm{~W} / \mathrm{m}^{2}$ \\
$\mathrm{DNI}$ & $-2 \mathrm{~W} / \mathrm{m}^{2}$ & $0.95 S_{0}\left(\mu_{0}\right)^{0 z}+10 \mathrm{~W} / \mathrm{m}^{2}$ \\
\hline
\end{tabular}

Dimana:

$\mu_{0}=\cos (5 Z \mathrm{~A})$

$5 Z \mathrm{~A}=$ solar zenith angle

$S_{\mathrm{a}}=S_{0} / A U^{2}$

$S_{0}=$ solar constant pada jarak rata rata bumi matahari (1367 $\left.\mathrm{W} / \mathrm{m}^{2}\right)$

$A U=$ jarak bumi dan matahari (dalam astronomical unit/ $\mathrm{AU}$ )
Perhitungan $A U$ yang digunakan dalam perhitungan solar zenith angle merujuk pada [12]:

$$
\begin{gathered}
A U=1.00014-0.01671 * \cos (g) \\
-0.00014 * \cos (2 g) \\
g=357.528+0.9856003 * n \\
n=j D-2452545 \\
I D=2432917.5+\text { delta } * 365+ \\
\text { leap }+ \text { day }+\frac{\text { hour }}{24}
\end{gathered}
$$

Dimana:

ID = Julian Date

delta = tahun -1949

leap = bagian integer dari (delta/4)

day $=$ hari dalam setahun $(1 \mathrm{Jan}=1,1 \mathrm{Feb}=$ 32, dst)

hour $=$ jam dalam sehari

Untuk melihat pengaruh awan terhadap pola radiasi matahari, perhitungan indeks kebeningan atmosfer harian (daily clearness index), $k_{\text {t }}$, pada periode 2018 - 2019 dilakukan untuk mengetahui kondisi perawanan di Stasiun Klimatologi Muaro Jambi. Indeks kebeningan atmosfer merupakan parameter yang digunakan untuk menandakan kondisi kecerahan atmosfer dan dapat digunakan sebagai indikator tutupan awan di suatu wilayah. Indeks kebeningan atmosfer memiliki rentang nilai $0-1$, dengan nilai 1 mengindikasikan kondisi atmosfer yang sepenuhnya cerah tanpa tutupan awan sama sekali. Nilai indeks kebeningan harian diperoleh dengan membandingkan jumlah radiasi matahari yang mencapai permukaan bumi dengan radiasi yang diterima di puncak atmosfer, dan dapat ditulis sebagai berikut:

$k_{t}=\frac{s}{s}$

$S_{0}=\frac{24}{\pi} I_{s c}\left(1+0.033 \cos \frac{3600}{365}\right)$

$\left(\cos \varphi \cos \delta \sin \omega_{3}+\frac{2 \pi \omega_{g}}{360} \sin \varphi \sin \delta\right)$

$\omega_{z}=\cos ^{-1}(-\tan \varphi \tan \delta)$

$\delta=23.45\left(360 \frac{294+E}{365}\right)$

Dimana:

$k_{t}=$ indeks kebeningan harian

$S=$ radiasi matahari harian $\left(\mathrm{Wh} / \mathrm{m}^{2}\right)$

$s_{a}=$ radiasi matahari harian di puncak atmosfer $\left(\mathrm{Wh} / \mathrm{m}^{2}\right)$

$I_{z c}=$ konstanta matahari $\left(1367 \mathrm{~W} / \mathrm{m}^{2}\right)$

$D=$ urutan hari dalam setahun (Jan $1=1$, Jan

$2=2$, Feb $1=32, \mathrm{dst}$ )

$p=$ lintang

$\delta=$ sudut deklinasi matahari

$\omega_{s}=$ sudut jam lokal (local hour angle) 


\section{Hasil dan Pembahasan}

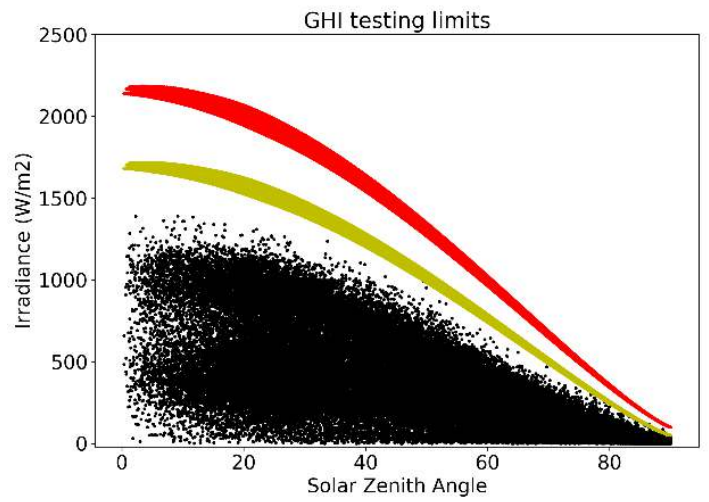

(a)

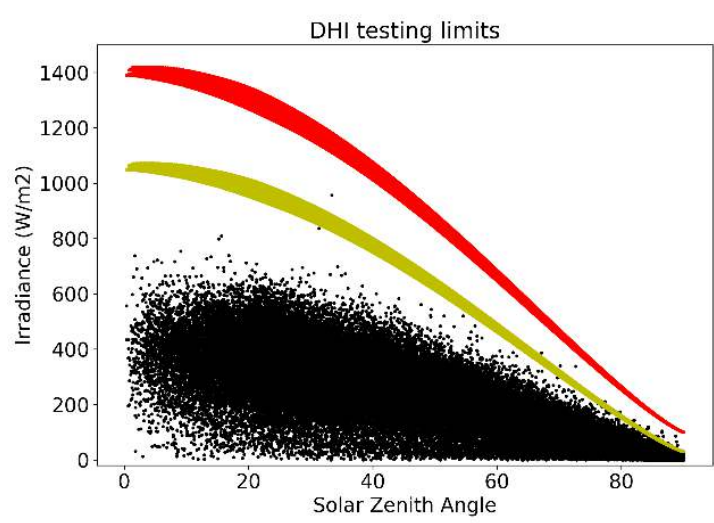

(b)

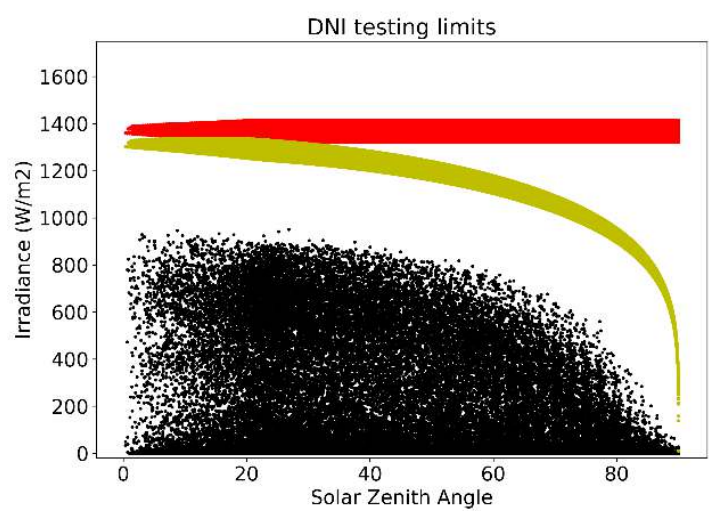

(c)

Gambar 5. Visualisasi dari proses kontrol kualitas data untuk (a) radiasi global, (b) radiasi baur, dan (c) radiasi langsung. Garis merah menandakan batas nilai yang memungkinkan secara fisis, garis kuning menandakan batas nilai ekstrim, titik hitam menandakan hasil pengukuran. (Sumber: pengolahan data)

Hasil Kontrol Kualitas Data. Hasil kontrol kualitas data yang dilakukan pada data radiasi matahari menunjukkan kualitas pengukuran data radiasi matahari di Stasiun Klimatologi Muaro Jambi. Secara umum, hasil pengukuran ketiga jenis radiasi menunjukkan rentang data yang baik selama periode 2018 - 2019. Namun demikian, beberapa nilai radiasi baur tercatat masih melampaui batas nilai ekstrim, terutama saat nilai SZA tinggi (Gambar 5.b). Hal ini dapat menandakan beberapa hal - kesalahan pengukuran lebih mungkin terjadi saat pagi dan sore hari (saat elevasi matahari rendah), atau intensitas radiasi baur yang memang cukup tinggi pada pagi dan sore hari. Setelah proses kontrol kualitas data, nilai yang melewati batas batas nilai yang ditentukan dieliminasi dan tidak digunakan dalam analisa selanjutnya.

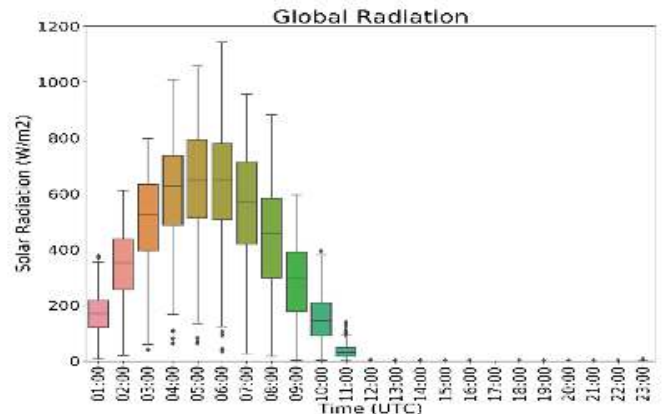

(a)

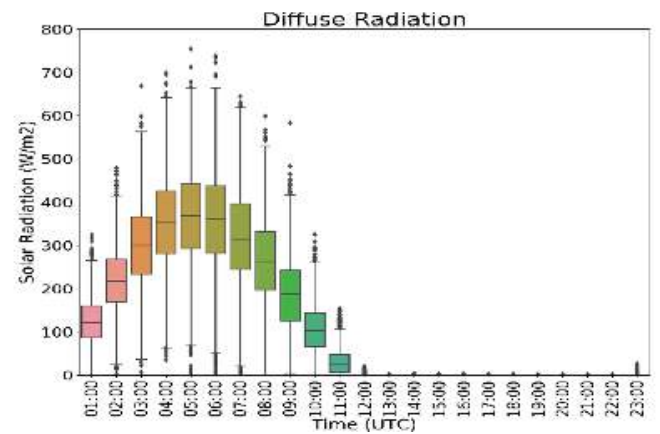

(b)

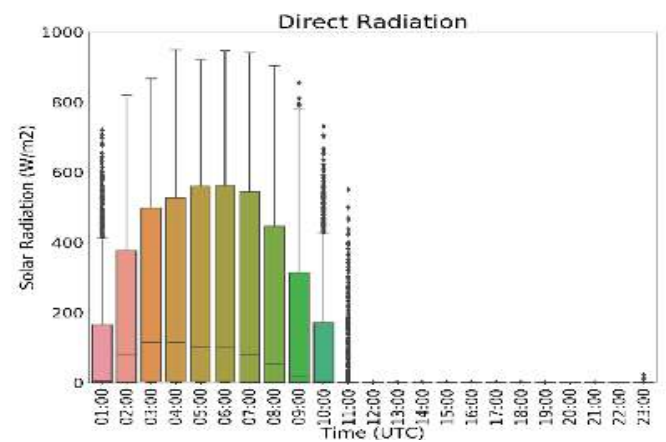

(c)

Gambar 6. Variasi diurnal (a) radiasi global, (b) radiasi baur, dan (c) radiasi langsung di Stasiun Klimatologi Muaro Jambi tahun 2018 - 2019. (Sumber: pengolahan data)

Variasi Diurnal. Ketiga grafik di atas (Gambar 6) menunjukkan pola diurnal rata rata dari ketiga jenis radiasi di wilayah Stasiun Klimatologi Muaro Jambi selama tahun 2018 2019. Radiasi matahari di wilayah Jambi umumnya mulai tercatat sejak pukul 23.00 - 
00.00 UTC (06.00 - 07.00 LT) hingga pukul 11.00 UTC (18.00 LT). Puncak insolasi sepanjang tahun terjadi sekitar pukul 06.00 UTC (13.00 LT), dimana tidak ada perbedaan yang signifikan terkait waktu puncak insolasi dari bulan ke bulan mengingat wilayah Jambi yang berdekatan dengan garis ekuatorial. Nilai maksimum radiasi global di wilayah Jambi pada tengah hari dapat mencapai $1200 \mathrm{~W} / \mathrm{m}^{2}$ dan nilai radiasi baur dapat mencapai $600 \mathrm{~W} / \mathrm{m}^{2}$ saat tengah hari.

Sebaran nilai (standar deviasi) radiasi langsung $\left(167.9 \mathrm{~W} / \mathrm{m}^{2}\right)$ lebih besar dibandingkan radiasi baur $\left(147.8 \mathrm{~W} / \mathrm{m}^{2}\right)$, mengingat nilai dari radiasi langsung sangat dipengaruhi oleh variabilitas tutupan awan. Radiasi langsung diukur dari satu arah, dengan demikian satu objek penghalang (awan) dapat sepenuhnya menghalangi komponen radiasi tersebut, sehingga memungkinkan bila nilai dari radiasi langsung berubah secara signifikan dalam rentang waktu yang tidak terlalu jauh. Sebaliknya, radiasi baur diperoleh dari segala arah sehingga memiliki nilai yang cenderung lebih konstan dan tidak sepenuhnya sensitif terhadap tutupan awan dibandingkan dengan radiasi langsung.
Variasi Bulanan. Berdasarkan pola rata rata bulanan, radiasi global di Stasiun Klimatologi Muaro Jambi mencapai puncak pada bulan Maret dan September (Gambar 7 - 8). Secara umum, variabilitas radiasi matahari yang diterima di permukaan bumi dipengaruhi oleh dua faktor, yakni faktor astronomis atau geografi (lintang), serta faktor atmosferik [13]. Matahari berada tegak lurus di atas wilayah ekuator dua kali dalam setahun, yakni bertepatan dengan kejadian equinox (20 Maret dan 23 September). Stasiun Klimatologi Muaro Jambi berada dekat dengan garis ekuatorial $\left(1.6^{\circ}\right.$ LS), sehingga pada bulan Maret - April dan September - Oktober, posisi matahari relatif lebih tinggi bagi pengamat di wilayah tersebut, yang berarti panjang atmosfer yang harus dilalui radiasi matahari untuk mencapai permukaan bumi di wilayah tersebut relatif lebih pendek. Hal ini menyebabkan penguatan intensitas radiasi matahari yang diterima di permukaan bumi pada bulan bulan tersebut, terutama saat tengah hari.

GHI Boxplot
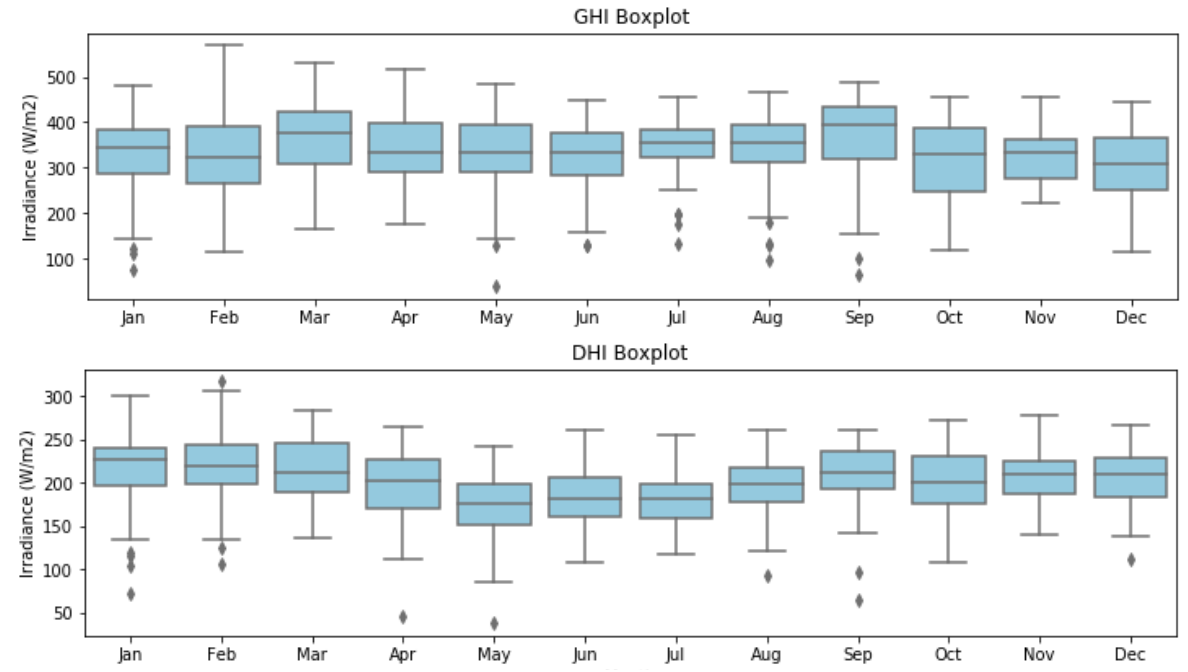

DNI Boxplot

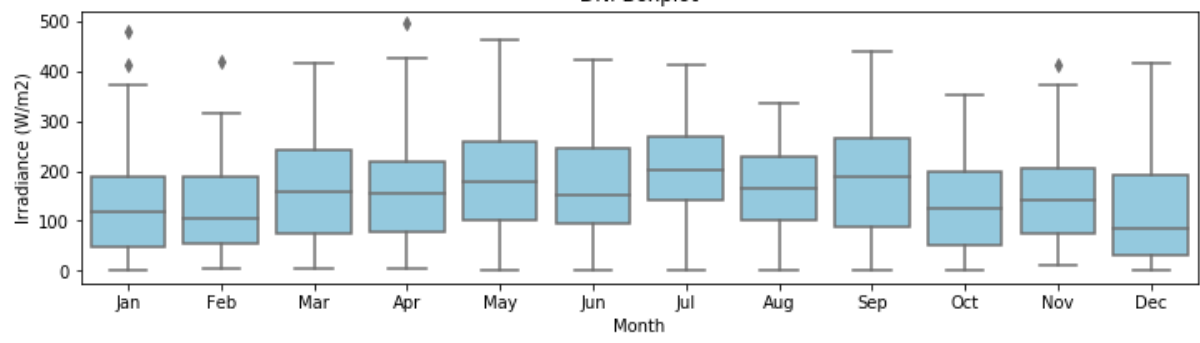

Gambar 7. Sebaran dari nilai radiasi global (GHI), baur (DHI), dan langsung (DNI) setiap bulan pada periode 2018 - 2019. (Sumber: pengolahan data) 


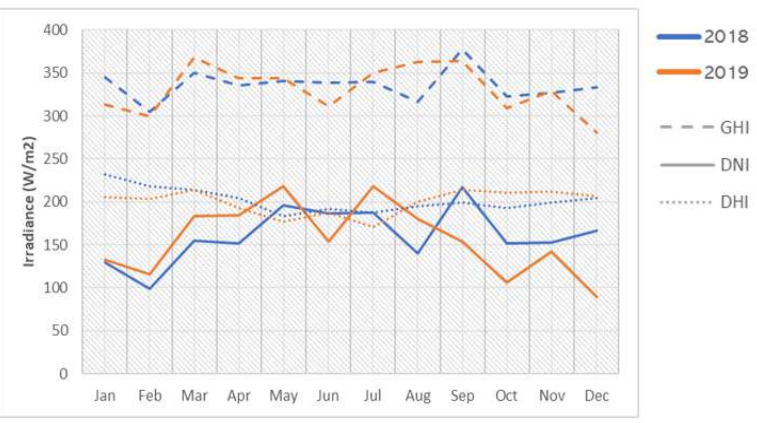

Gambar 8. Nilai rata rata radiasi global $(\mathrm{GHI})$, baur (DHI), dan langsung (DNI) pada periode 2018 2019.

Nilai rata rata akumulasi harian radiasi global di Stasiun Klimatologi Muaro Jambi pada tahun 2018 - 2019 mencapai $4.4 \pm 1.0 \mathrm{kWh} / \mathrm{m}^{2}$ day $^{-1}$. Nilai tersebut setara dengan nilai radiasi matahari harian di wilayah Indonesia yang ditemukan dalam beberapa penelitian terdahulu [14 - 16]. Nilai ini juga menandakan jumlah potensi energi surya harian yang bisa diperoleh di wilayah Jambi. Standar deviasi dari nilai radiasi harian terlihat paling besar pada musim basah (DJF) $\left(0.97-1.2 \mathrm{kWh} / \mathrm{m}^{2}\right)$ dan relatif lebih kecil pada bulan kering (JJA) $(0.8-0.84$ $\mathrm{kWh} / \mathrm{m}^{2}$ ), yang menunjukkan bahwa kejadian hujan dan tutupan awan dapat menjadi masalah untuk memperoleh input radiasi matahari yang stabil. Untuk wilayah dengan tutupan awan yang cukup signifikan, ini dapat menjadi masalah dalam kegiatan produksi energi surya. Di beberapa wilayah di Indonesia, jumlah radiasi maksimum juga secara umum tercapai saat musim kering, terutama jika bertepatan dengan posisi matahari yang tinggi $[3-4]$.

Radiasi Matahari dan Tutupan Awan. Sebagaimana disebutkan dalam bagian sebelumnya, selain faktor astronomis seperti gerak semi-tahunan matahari, keberadaan konstituen atmosfer lain juga menentukan besaran radiasi matahari yang mencapai bumi. Wilayah Indonesia didominasi dengan pertumbuhan awan yang kuat, sehingga berpotensi menghalangi radiasi yang mencapai permukaan bumi. Pengaruh perawanan terhadap radiasi matahari dapat terlihat dari profil radiasi matahari pada saat hari cerah (clear sky) dan hari berawan (overcast) (Gambar 9 - 10). Untuk menentukan hari cerah dan hari berawan, indeks kebeningan harian (daily clearness index) di Stasiun Klimatologi Muaro Jambi untuk tahun 2018 - 2019 dihitung, dimana semakin besar nilai indeks kebeningan harian menandakan kondisi perawanan minimum. Dalam periode 2018 - 2019, nilai indeks kebeningan harian di Stasiun Klimatologi Muaro Jambi berkisar antara $0.05-0.67$.
Pada hari dengan kondisi perawanan maksimum (clearness index<0.2), terlihat bahwa radiasi global sepenuhnya dipengaruhi oleh komponen radiasi baur, dan hampir tidak ada komponen radiasi langsung sepanjang hari (Gambar 9). Pada hari dengan nilai clearness index paling tinggi selama periode 24 bulan tersebut, terlihat bahwa pengaruh dari awan masih cukup dominan terhadap sinar matahari yang mencapai permukaan bumi (Gambar 10). Ini menandakan kuatnya pertumbuhan awan di wilayah Jambi, dimana tidak terdapat satupun hari dengan kondisi langit sepenuhnya cerah.

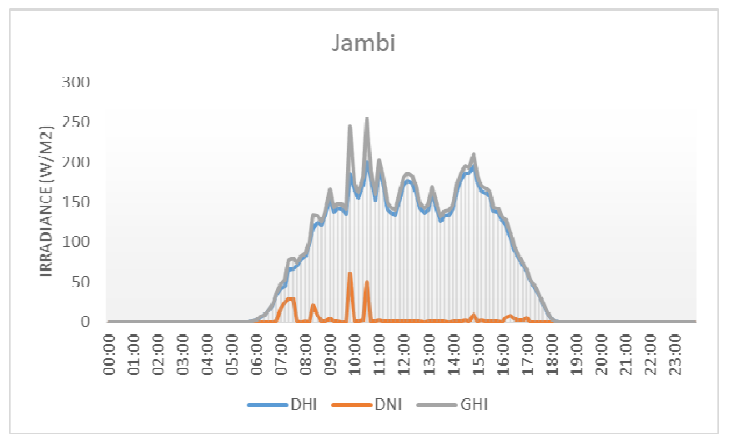

Gambar 9. Profil rata rata radiasi matahari di Stasiun Klimatologi Muaro Jambi pada hari berawan (clearness index<0.2). (Sumber: pengolahan data)

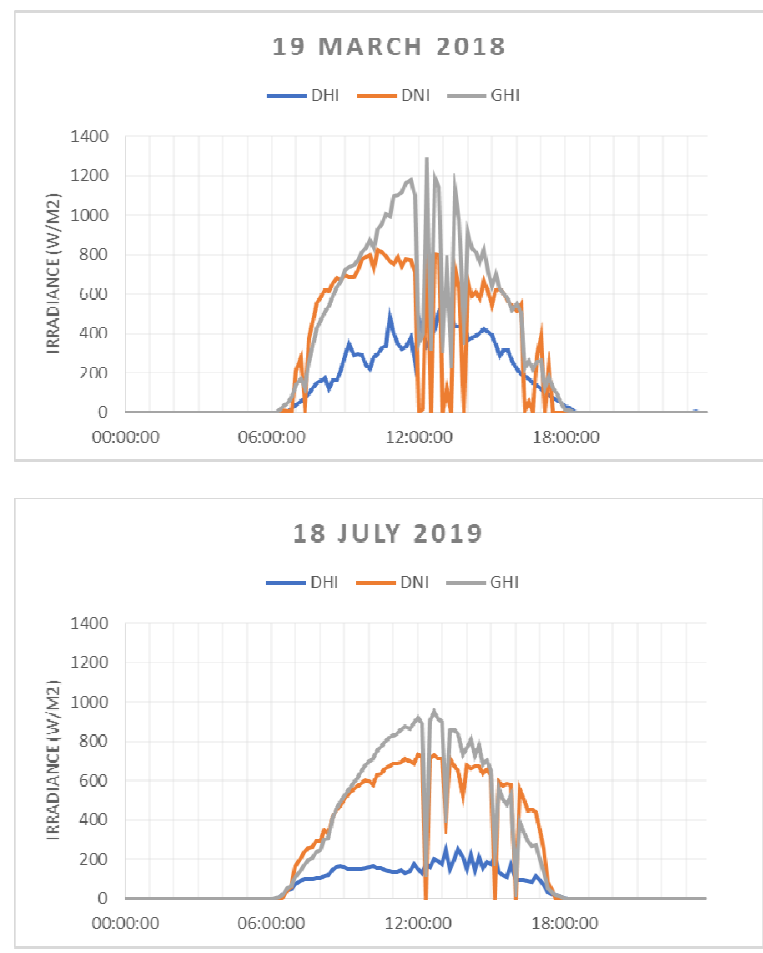

Gambar 10. Profil radiasi matahari pada beberapa hari paling 'cerah' di Stasiun Klimatologi Muaro Jambi. (Sumber: pengolahan data) 
Di wilayah tropis, radiasi baur cenderung memiliki proporsi yang lebih besar dibandingkan dengan radiasi baur di wilayah lintang tinggi, dikarenakan kondisi perawanan dan kelembapan yang lebih signifikan [17 - 19]. Tiga proses yang dapat melemahkan intensitas radiasi matahari yang mencapai permukaan bumi mencakup pembauran oleh molekul gas, penyerapan oleh molekul gas di atmosfer, dan pembauran oleh partikel padat dan gas terkondensasi (cloud droplet) [11]. Dibandingkan dengan atenuasi yang diakibatkan oleh molekul gas dan partikel padat (kering), pembauran yang dihasilkan oleh awan (uap air) memiliki pengaruh yang lebih besar pada profil radiasi matahari. Atenuasi radiasi matahari yang disebabkan oleh awan bahkan dapat menunjukkan pengaruh fenomena iklim skala besar seperti El Niño terhadap intensitas radiasi matahari di beberapa wilayah terdampak [19-20].

\section{Kesimpulan}

Pengukuran data radiasi matahari di Stasiun Klimatologi Muaro Jambi telah dilakukan sejak tahun 2017 dengan resolusi temporal yang tinggi dan memiliki kualitas yang baik. Nilai dari ketiga parameter radiasi mencapai puncak pada pukul 06.0 UTC, dan radiasi langsung secara umum memiliki sebaran yang lebih besar dibandingkan radiasi baur. Pola musiman radiasi matahari dipengaruhi oleh gerak semi tahunan matahari, dimana nilai maksimum dari radiasi global terjadi pada bulan Maret dan September, atau saat periode equinox. Tutupan awan yang signifikan di wilayah Jambi sepanjang tahun mempengaruhi sebaran jumlah radiasi matahari yang mencapai permukaan bumi.

\section{Daftar Pustaka}

[1] Kopp, G. (2014). An assessment of the solar irradiance record for climate studies. Journal of Space Weather and Space Climate, 4, A14, doi:10.1051/swsc/2014012.

[2] Kafka, J., and M. Miller. (2019). A climatology of solar irradiance and its controls across the United States: Implications for solar panel orientation. Renewable Energy, 135, 897-907,

doi:10.1016/j.renene. 2018.12.057.

[3] Octavianti, A., Muliadi, Apriansyah. (2018). Estimasi Intensitas Radiasi Matahari di Wilayah Kota Makassar. Prisma Fisika. 6(3), 152 - 159.

[4] Utomo, Y.S. (2017). Prediksi radiasi surya global bulanan kota bandung menggunakan data LPM (lama penyinaran matahari). Jurnal Material dan Energi Indonesia. 7(2), 21 - 27.

[5] Rumbayan, M., Abudureyimu, A. and Nagasaka, K. (2012). Mapping of solar energy potential in Indonesia using artificial neural network and geographical information system. Renewable and Sustainable Energy Reviews. 16(3), 1437-1449.
[6] Morrison, G. and Sudjito. (1992). Solar Radiation Data for Indonesia. Solar Energy. 49(1), 65 - 76.

[7] Sianturi, Y., Marjuki, Sartika, K. (2020). Evaluation of ERA5 and MERRA2 reanalyses to estimate solar irradiance using ground observations over Indonesia region. In: Astechnova International Energy Conference.

[8] Anonim.(2012).Sun Tracker STR-21G/22G/32G Instruction Manual Ver.7.Japan

[9] Anonim.(2016). Manual Book of MS-57 Pyrheliometer Ver.3.Japan.

[10] Duffie, J., and W. Beckman. (2013). Solar engineering of thermal processes. Wiley, Hoboken, N.J.,.

[11] Long, C. N., and E. G. Dutton. (2002). BSRN Global Network recommended QC tests, V2.0. BSRN Technical Report.

[12] (2018) Guide to meteorological instruments and methods of observation. World Meteorological Organization, Geneva, Switzerland.

[13] Kimball, H. (1932). Solar Radiation as a Meteorological Factor. Reviews of Modern Physics, 4, 259-277, doi:10.1103/revmodphys.4.259.

[14] Septiadi D., Nanlogy P., Souissa M., Rumlawang F.Y. (2009). Proyeksi potensi energi surya sebagai energi terbarukan (studi wilayah Ambon dan sekitarnya). Jurnal Meteorologi dan Geofisika. 10(1), 22 - 28.

[15] Sianturi Y. (2020). Estimating the solar energy potential over Indonesia region using daily sunshine duration. International Journal of Science and Research. 9(5), $1069-1073$.

[16] Handayani N.A., Ariyanti D. (2012). Potency of solar energy application in Indonesia. International Journal of Renewable Energy Development. 1(2), 33 - 38.

[17] Okogbue, E., J. Adedokun, and B. Holmgren. (2009). Hourly and daily clearness index and diffuse fraction at a tropical station, Ile-Ife, Nigeria. International Journal of Climatology, 29, 1035-1047, doi:10.1002/joc.1849.

[18] Arthur, Y., F. Oduro, and W. Obeng-Denteh. (2016). Statistical Analysis of Hourly Solar Radiation in Kumasi - Ghana: Bayesian Approach. Journal of Scientific Research and Reports, 10, 1-23, doi:10.9734/jsrr/2016/12030.

[19] Gu, L., J. Fuentes, M. Garstang, J. Silva, R. Heitz, J. Sigler, and H. Shugart. (2001). Cloud modulation Of surface solar irradiance at a pasture site in southern Brazil. Agricultural and Forest Meteorology, 106, 117129, doi:10.1016/s0168-1923(00)00209-4.

[20] Díaz-Torres, J. et al. (2017). Assessment of the modulation effect of rainfall on solar radiation availability at the Earth's surface. Meteorological Applications, 24, 180-190, doi:10.1002/met.1616. 